\title{
When dreams become a royal road to confusion: Realistic dreams, dissociation, and fantasy proneness
}

Citation for published version (APA):

Rassin, E. G. C., Merckelbach, H. L. G. J., \& Spaan, V. J. E. (2001). When dreams become a royal road to confusion: Realistic dreams, dissociation, and fantasy proneness. Journal of Nervous and Mental Disease, 189(7), 478-481. https://doi.org/10.1097/00005053-200107000-00010

Document status and date:

Published: 01/01/2001

DOI:

10.1097/00005053-200107000-00010

Document Version:

Publisher's PDF, also known as Version of record

\section{Please check the document version of this publication:}

- A submitted manuscript is the version of the article upon submission and before peer-review. There can be important differences between the submitted version and the official published version of record.

People interested in the research are advised to contact the author for the final version of the publication, or visit the DOI to the publisher's website.

- The final author version and the galley proof are versions of the publication after peer review.

- The final published version features the final layout of the paper including the volume, issue and page numbers.

Link to publication

\footnotetext{
General rights rights.

- You may freely distribute the URL identifying the publication in the public portal. please follow below link for the End User Agreement:

www.umlib.nl/taverne-license

Take down policy

If you believe that this document breaches copyright please contact us at:

repository@maastrichtuniversity.nl

providing details and we will investigate your claim.
}

Copyright and moral rights for the publications made accessible in the public portal are retained by the authors and/or other copyright owners and it is a condition of accessing publications that users recognise and abide by the legal requirements associated with these

- Users may download and print one copy of any publication from the public portal for the purpose of private study or research.

- You may not further distribute the material or use it for any profit-making activity or commercial gain

If the publication is distributed under the terms of Article $25 \mathrm{fa}$ of the Dutch Copyright Act, indicated by the "Taverne" license above, 


\title{
When Dreams Become a Royal Road to Confusion: Realistic Dreams, Dissociation, and Fantasy Proneness
}

\author{
ERIC RASSIN, Ph.D., ${ }^{1}$ HARALD MERCKElBACH, Ph.D., ${ }^{2}$ and VICTOR SPAAN, M.A. ${ }^{2}$ \\ Scientific discussions about false memories have, so far, mainly focused on \\ external determinants (e.g., therapeutic interventions). However, in some cases, \\ false memories might develop more spontaneously. For example, difficulties in \\ distinguishing between dreams and reality may lead to false memories. The present \\ article discusses two studies ( $N=85$ and 255 , respectively) that examined to what \\ extent such difficulties occur. In both studies, a nontrivial minority of respondents \\ (11.8\% and 25.9\%, respectively) reported that they had had the experience of not \\ being able to discriminate between dream and reality. As expected, respondents \\ who reported this type of confusion scored higher on fantasy proneness and \\ dissociation measures than respondents who did not report this confusion.
}

—J Nerv Ment Dis 189:478-481, 2001

In recent years, false memories have been the focus of lively discussions. For example, skeptics have proclaimed false memories as an alternative explanation for recovered memories (i.e., memories of childhood traumas that were lost for longer time periods but are then recovered during psychotherapy; e.g., Loftus, 1993; Poole et al., 1995). False memories have also been studied in the context of false confessions. Research has shown that, during police interrogations, people may become overwhelmed by post-hoc misinformation about a crime and can, subsequently, be brought to believe that they were involved in that crime, whereas, in fact, they were not (Gudjonsson, 1992; Kassin, 1997).

Experimental studies on false memories have emphasized external sources such as therapeutic interventions (e.g., guided imagination, Garry et al., 1996; hypnosis, Spanos, 1996; dream interpretation, Mazzoni and Loftus, 1998), and suggestive techniques during police interviews (Kassin, 1997) as the primary antecedents of false memories. However, there are reasons to believe that false memories may also develop in a more spontaneous fashion, that is, may arise from internal sources. For example, Lipinski and Pope (1994) described several cases in which patients were diagnosed as suffering from posttraumatic stress disorder. Although this diagnosis was partly based on the presence of traumatic flashbacks, these flashbacks turned out to be obses-

\footnotetext{
${ }^{1}$ Department of Law (Metajuridica), Maastricht University, P.O. Box 616, 6200 MD Maastricht, The Netherlands. Send reprint requests to Dr. Rassin.

${ }^{2}$ Department of Psychology, Maastricht University, P.O. Box 616, 6200 MD Maastricht, The Netherlands.
}

sional fantasies rather than trauma memories. Hence, it seems that false memories may be rooted in failures to differentiate between dreams or lively fantasies on the one hand and reality on the other.

Experimental evidence for this possibility comes from a study by Mazzoni and Loftus (1996). These authors found that participants tend to mistake words uniquely referring to their own dreams for items generated by the experimenter. More precisely, the authors invited their participants to describe their recent dreams in a series of single words. A few days later, participants were given a list of words and were asked to estimate the number of letters that these words consisted of. Some of the words were generated by the experiment leader, whereas others were derived from the subjects' selfreported list of dream-describing words. When asked whether they recognized any of the words in the list, subjects frequently failed to recognize words as originating from their own dream descriptions. Although these results suggest that people may spontaneously develop memories of "events" that were actually internally generated memories (i.e., dreams), the question remains whether this also occurs outside the laboratory, to an extent that makes it relevant to discussions about false memories.

It can be argued that dreams can only serve as powerful antecedents of false memories if two conditions are met. First, the dream must be highly realistic and must have an unpleasant content, as is usually the case with recovered memories and false confessions. Second, the dream must give rise to a behavioral consequence (such as a changed attitude toward persons who figure in the dream). The work 
of Ohayon et al. (1996) bears relevance to the first issue. These authors found that a substantial percentage of healthy volunteers reported to have very vivid and realistic dreams at least twice a week. Thirty-seven percent of the respondents experienced such dreams during sleep onset (hypnagogic hallucinations), whereas $12 \%$ experienced these dreams primarily during awakening (hypnopompic hallucinations).

The present studies examined the prevalence of highly realistic dreams in nonclinical samples. We also explored to what extent such dreams may have behavioral consequences (e.g., confronting people who acted in the dream). Finally, people reporting realistic dreams were compared with people without such dreams with respect to fantasy proneness and dissociation. This was done because previous work has shown that both phenomena are implicated in the tendency to develop false memories (e.g., Hyman and Billings, 1998).

\section{Study 1}

\section{Participants}

Undergraduate students $(N=85 ; 77$ women $)$ completed a short questionnaire about dreams. Mean age of this sample was 22.4 years ( $\mathrm{SD}=4.8$; range: 19 to 48 years).

\section{Results}

The questionnaire contained five items. First, participants were asked whether they had ever experienced such a realistic dream that, for a short period of time after waking up, it left them thinking it had really happened. Fifty-eight participants (68\%) acknowledged having experienced such realistic dreams. The second item concerned the frequency of this type of dream: its average frequency was 2.0 times per month $(\mathrm{SD}=3.4)$. The third item addressed sleep disturbances: none of the participants reported such disturbances. The next two questions addressed whether realistic dreams sometimes tend to take the form of false memories. Participants were asked whether they had ever acted against others on the basis of dream content; this seemed to apply to five respondents (5.8\%). The question of whether participants, at present, had memories that they were unable to trace to a real event or dream was endorsed by six respondents (7.1\%). Given that one respondent endorsed the latter two questions, it can be argued that 10 participants (11.8\%) reported having experienced realistic dreams with possible behavioral consequences.
TABLE 1

Overview of the Main Results of the Two Studies

\begin{tabular}{lcc}
\hline & Study 1 & Study 2 \\
\hline $\begin{array}{l}\text { Sample size } \\
\text { Respondents reporting realistic }\end{array}$ & $N=85$ & $N=255$ \\
$\quad$ dreams & 58 & 199 \\
$\begin{array}{l}\text { Respondents reporting dreams with } \\
\text { behavioral consequences }\end{array}$ & $(68 \%)$ & $(78 \%)$ \\
$\quad$ & 5 & 25 \\
$\begin{array}{l}\text { Respondents reporting memories of } \\
\text { uncertain origin }\end{array}$ & $(5.8 \%)$ & $(9.8 \%)$ \\
& $(7.1 \%)$ & $(16.1 \%)$ \\
\hline
\end{tabular}

\section{Study 2}

\section{Participants}

In a second study, we sought to replicate the results of study 1 . Thereto, a similar, yet more extended questionnaire was completed by 255 respondents (175 women). Mean age was 21.1 years ( $\mathrm{SD}=$ 2.3; range: 18 to 38 years).

\section{Results}

Here, 199 respondents (78\%) reported familiarity with highly realistic dreams. The mean frequency of such dreams was 2.3 per month $(\mathrm{SD}=3.3) .^{3}$ Participants were asked to indicate how realistic these dreams were using a visual analogue scale (VAS) ranging from 0 (moderately) to 100 (extremely). The mean score on this VAS was $64.5(\mathrm{SD}=18.6)$. A total of 115 respondents (58\%) indicated that they experienced realistic dreams primarily during awakening, 6 respondents (3\%) reported dreaming realistically during sleep onset, and 78 participants (39\%) were unable to indicate during which stage realistic dreams generally occurred. Although none of the participants suffered from serious sleep disturbances, 58 respondents (29.1\%) reported irregular sleep patterns. In this sample, 25 participants (9.8\%) reported having acted against others on the basis of what turned out to be a dream instead of a real event. Forty-one participants (16.1\%) currently had memories of which the origin (dream vs. real event) was unclear to them. In sum, as in study 1, a small but considerable minority reported having experienced dreams with possible behavioral consequences, and thus with the potential to develop false memories. Table 1 summarizes the main findings of the two studies.

\footnotetext{
${ }^{3}$ It should be noted that in both studies, the distribution of dream frequency was skewed to the right (skewness $=2.7$ and 3.0 , respectively). In both studies, the median was 1.0, whereas the ranges were .1 to 16 and .01 to 20 , respectively.
} 
TABLE 2

Mean Scores (and Standard Deviations) of Participants with ( $\mathrm{N}=22)$ and without $(\mathrm{N}=26)$ Persistent Realistic Dreams

\begin{tabular}{lcccc}
\hline & $\begin{array}{c}\text { Realistic } \\
\text { Dreamers }\end{array}$ & $\begin{array}{c}\text { Nonrealistic } \\
\text { Dreamers }\end{array}$ & $t$ & $p^{a}$ \\
\hline $\mathrm{CEQ}^{b}$ & $7.6(5.2)$ & $4.5(3.3)$ & 2.5 & .01 \\
$\mathrm{DES}^{c}$ & $18.2(13.9)$ & $10.9(4.8)$ & 2.3 & .01 \\
\hline
\end{tabular}

${ }^{a}$ All presented $p$-values are one-tailed.

${ }^{b}$ Creative Experiences Questionnaire.

${ }^{c}$ Dissociative Experiences Scale.

\section{Individual Differences}

To explore whether the tendency to experience realistic dreams with behavioral consequences is attributable to individual differences, two groups of participants were selected from the sample in study 2. The first group consisted of 26 respondents who never dreamt realistically, whereas the second group consisted of 22 respondents who had either acted upon the content of a dream, or currently had memories of uncertain origin. Thus, a sample of 48 participants (36 women; mean age $=22.1 ; \mathrm{SD}=3.5$; range: 18 to 38 ) were asked to complete the following questionnaires.

The Creative Experiences Questionnaire (CEQ; Merckelbach et al., in press) contains 25 yes/no items (e.g., "I still remember a lot of events that happened to me before I reached the age of three years"). Every endorsed item yields one point. Consequently, total scores range from 0 to 25 with higher scores indicating higher levels of fantasy proneness.

The Dissociative Experiences Scale (DES; Bernstein and Putman, 1986) consists of 28 items (e.g., "Being not sure if a remembered event happened or was a dream"). The respondent indicates to what extent each statement applies to him/her by ticking a visual analogue scale (VAS) ranging from 0 (not at all) to 100 (very much). Total DES scores are expressed as the mean of the 28 items, that is, they range from 0 to 100 , with higher scores indicating more self-reported dissociative symptoms.

The mean scores of both groups are presented in Table 2. As can be seen, participants with realistic dreams scored higher on both measures than participants without such dreams, although it should be noted that scores of the former group remained within the normal range. Interestingly, women were overrepresented in the realistic dream group. Of the 22 realistic dreamers, 20 were women, whereas 16 of the 26 nonrealistic dreamers were women $\left(\chi^{2}=5.5\right.$, $p=.02$ ). After the potential influence of gender was corrected for in an ANOVA, the main effect of (non)realistic dreams remained significant for both measures (both $p \mathbf{s}<.05$ ).

\section{Discussion}

Our results suggest that in nonclinical samples, realistic dreams occur relatively frequently: that is, $68 \%$ to $78 \%$ of the respondents reported being familiar with such dreams. As well, a nontrivial minority of respondents reported having experienced more persistent realistic dreams such that they either had believed for some period of time that the dream content referred to real events (which led them to confront others; $6 \%$ to $10 \%$ ), or at present had memories of which they were uncertain whether they pertained to a dream or real event ( $7 \%$ to $16 \%$ ). Additionally, these persistent realistic dreams were found to be linked to heightened levels of fantasy proneness and dissociation, although no clinical ranges were reached.

How should one interpret the finding that a nontrivial minority of nonclinical participants was familiar with the experience of confusing dreams with real events? One possibility is that this phenomenon is a special case of what has been termed source monitoring errors (Johnson et al., 1993), in which people confuse memories of their imaginations with memories of real events. The fact that participants who reported realistic dreams also had heightened fantasy proneness and dissociation scores supports this interpretation, because one common theme in both measures is the tendency to misattribute imaginations to reality. Interestingly, there is not only a considerable overlap between fantasy proneness and dissociation (e.g., Merckelbach et al., 1999), but both measures also covary with schizotypy (e.g., Merckelbach et al., 2000b). The potential link between dream-reality confusion and schizotypy warrants further study, because there are strong indications that schizotypy is a powerful predictor of nightmare distress (e.g., Claridge et al., 1997). Indeed, some authors have interpreted nightmares and schizotypy characteristics as manifestations of relatively permeable boundaries between internal imaginations and external reality (e.g., Hartman, 1991).

Another and more mundane interpretation of our findings is that they reflect fantasy prone individuals' tendency to over-endorse symptoms (e.g., Merckelbach et al., 2000a). That is, self-reports of highly realistic dreams might be an artifact of the positive response bias linked to fantasy proneness. What argues against such an interpretation is that fantasy proneness scores of realistic dreamers were within the normal range (e.g., Merckelbach et al., in press). Nevertheless, a clear limitation of the current studies is that they relied on self-reports. This could produce an overestimation of the prevalence of realistic dreams but could also lead to an underesti- 
mation of the phenomenon (some participants may still mistake their dreams for real events).

\section{Conclusion}

The main implication of the current findings is that in a minority of cases, false memories may be rooted in dreams. Thus, our findings concur with those of Mazzoni and Loftus (1996), who found that confusion between dream and reality can be induced in an experimental context, and with those of Ohayon et al. (1996), who noted that realistic dreams are prevalent in the general population, during sleep onset and waking up.

It should be noted that respondents in our study reported adverse dream contents (e.g., being held prisoner, being molested, being insulted, or being prosecuted). This makes the findings relevant to the ongoing discussion about false memories and their legal ramifications. Unpleasant, or even traumatic, memories may in some cases pertain to nothing more than a dream (see also Pendergrast, 1995). Previous studies in this domain have emphasized the role of suggestive therapeutic techniques in the etiology of false memories. The present findings seem to imply that at least in some cases, such memories may arise spontaneously, that is, in the absence of external forces. Clearly, this spontaneous pathway to false memories requires further study.

\section{References}

Bernstein EM, Putman FW (1986) Development, reliability, and validity of a dissociation scale. J Nerv Ment Dis 174:727-735.

Claridge G, Clark K, Davis C (1997) Nightmares, dreams, and schizotypy. Br J Clin Psychol 36:377-386.
Garry M, Manning CG, Loftus E, Sherman SJ (1996) Imagination inflation: Imagining a childhood event inflates confidence that it occurred. Psychon B Rev 3:208-214.

Gudjonsson GH (1992) The psychology of interrogations, confessions and testimony. Chichester: Wiley.

Hartman E (1991) Boundaries in the mind: A new psychology of personality. New York: Basic Books.

Hyman IE, Billings FJ (1998) Individual differences and the creation of false memories. Memory 16:1-20.

Johnson MK, Hashtroudi S, Lindsay DS (1993) Source monitoring. Psychol Bull 114:3-28.

Kassin SM (1997) The psychology of confession evidence. Am Psychol 52:221-233.

Lipinski JF, Pope HG (1994) Do flashbacks represent obsessional imagery? Compr Psychiatry 35:245-247.

Loftus EF (1993) The reality of repressed memories. Am Psychol 48:518-537.

Mazzoni GAL, Loftus EF (1996) When dreams become reality. Conscious Cogn 5:442-462.

Mazzoni GAL, Loftus EF (1998) Dream interpretation can change beliefs about the past. Psychotherapy 35:177-187.

Merckelbach H, Horselenberg R, Muris P (in press) The Creative Experiences Questionnaire (CEQ): A brief self-report measure of fantasy proneness. Pers Indiv Differ.

Merckelbach H, Muris P, Horselenberg R, Stougie S (2000a) Dissociative experiences, response bias, and fantasy proneness in college students. Pers Indiv Differ 28:49-58.

Merckelbach H, Muris P, Rassin E (1999) Fantasy proneness and cognitive failures as correlates of dissociative experiences. Pers Indiv Differ 26:961-967.

Merckelbach H, Rassin E, Muris P (2000b) Dissociation, schizotypy, and fantasy proneness in undergraduate students. J Nerv Ment Dis 188:428-431.

Ohayon MM, Priest RG, Caulet M, Guilleminault C (1996) Hypnagogic and hypnopompic hallucinations: Pathological phenomena? Br J Psychiatry 169:459-467.

Pendergrast M (1995) Believing the unbelievable: Linking recovered memories to hypnosis, dreams, sleep paralysis, and panic attacks. Skeptic 3:52-57.

Poole DA, Lindsay DS, Memon A, Bull R (1995) Psychotherapy and the recovery of memories of childhood sexual abuse: U.S. and British practioners' opinions, practices, and experiences. $J$ Consult Clin Psychol 63:426-437.

Spanos NP (1996) Multiple identities and false memories: A sociocognitive perspective. Washington, DC: American Psychological Association. 